\title{
Bioethics and Biopolitics in Cultivating Bios and Biotopes
}

\author{
Hans-Martin Sass ${ }^{1}$ (])
}

'If a Muslim plants a tree or sows a field, and men and beasts and birds eat from it, all of it is charity from him' (Muslim, Kitab al-Musaqat, 10)

\begin{abstract}
For millennia, religions and cultures all over the world have recognized the interdependence and interaction of all forms of life; prophets, educators and rulers called for charity, health and happiness not only of individuals but also of families, communities and of animals and birds in natural and cultural biotopes. Fritz Jahr defined the Bioethical Imperative 'Respect every living being as an end in itself and treat it, if possible, as such'- as an orientational tool for compassionate and competent human life and culture in healthy natural and social biotopes. Medicine is more than a repair shop for human bodies; caring for the health of fellow humans requires both, expertise and ethics, competence and compassion. This paper reviews visions and rules in the ethics and politics of bios across cultures and stresses the importance of bioethics and biopolitics for the 21th century.
\end{abstract}

\section{Keywords}

Bios $\bullet$ Biotope $\bullet$ Bioethics $\bullet$ Biopolitics $\bullet$ Compassion $\bullet$ Competence $\bullet$ Integration

\section{Canlılar ve Yaşam Alanları Geliştirmede Biyoetik ve Biyopolitik}

\section{Öz}

Binlerce yıldır tüm dünyadaki dinler ve kültürler, tüm yaşam çeşitlerinin karşılıklı bağımlıı̆̆ııı ve etkileşimini kabul etmişlerdir. Peygamberler, eğitimciler ve yöneticiler, yalnızca bireylerin değil ailelerin, toplumların, hayvanların ve kuşların da doğal ve kültürel yaşam alanlarında hayır, sağlık ve mutluluk çağrısında bulunmuşlardır. Fritz Jahr, biyoetiğe ilişkin buyruğu belirlemiştir: "Her canlıya kendi başına bir amaç olarak saygı göster ve mümkün olduğunca onlara buna göre -sağlıklı doğal ve sosyal yaşam alanlarında merhametli ve yetkin insan yaşamı ve kültürü için oryantasyon aracı olarakdavran." Tıp, insan bedenleri için bir tamir atölyesinden daha fazlasıdır; insan hemcinslerimizin sağlık bakımını üstlenmek hem uzmanlık ve etik hem de yetkinlik ve merhamet gerektirir. Bu makale, kültürler arası canlı etiği ve politikalarındaki görüş ve kuralları gözden geçirmekte ve 21. yüzyıl için biyoetik ve biyopolitiğin önemini vurgulamaktadır.

\author{
Anahtar Kelimeler \\ Canlı • Yaşam alanı • Biyoetik • Biyopolitik • Merhamet • Yetkinlik • Entegrasyon
}

\footnotetext{
1 Correspondence to: Professor, Founding Member of the Zentrum fuer Medizinische Ethik (Center for Medical Ethics) at Ruhr University, Bochum-Germany. Email: sasshm@aol.com

To cite this article: Hans Martin Sass, "Bioethics and Biopolitics in Cultivating Bios and Biotopes," darulfunun ilahiyat 29/2, (December, 2018): 167-179. https://dx.doi.org/10.26650/di.2018.29.2.0110
} 


\section{Bioethics and Biopolitics in Cultivating Bios and Biotopes}

\section{Bios is Integrating, Interdepending, Cooperating, Competing}

Comparative biology and my own life experiences tell me that as a living organism, I am not independent from other organisms at all. I would not exist without my mother and father; I would not be able to live without food and drink, air to breathe, sleep, a house for shelter and clothes to keep warm, not without microbes in my intestine co-digesting foods with me and for me, not without machines and supermarkets for civilized and convenient life, not without electricity, cellphones and televisions for communication and networking, sex and love for fun and compassion, friends and colleagues for successful and enjoyable living and working.

And, I am not alone in these interrelations: protons, neutrons, atoms, molecules are not independent either, but interact permanently with each other; so do microbes, plants, animals, original natural and agricultural biotopes, depending on oxygen, water and other support for life and prosperity; similarly, planets, suns, moons, milky ways, universes and multiverses interact with each other, are born and will die just like we all will. Living organisms are in permanent modification, depending on and influencing other organisms. The multiverse and universe are not the same as they were billions of years ago; our globe has dramatically changed over the last 100.000 years since our ancestors descended from the trees of Africa, migrated all around the globe, modified lands, waters, and bios and biotopes with the use of various forms of technology, and by building houses, cities and walls, by creating weapons and machines, by founding kingdoms, republics and democracies. Microbes, plants, animals, and humans are all different, yet similar: 'he er bu tong' - similar but different, hopefully in harmony, as Confucius stated. ${ }^{2}$

However, there is also a quest for autonomy, independence, self-determination and freedom within all of us. The desire not to be enslaved, exploited and dominated by others might be an essential characteristic for all beings; for us humans it has definitely been a vision for millennia. Not to be forced by others to serve as slaves, not to be dependent on others for economic reasons, not to be exploited in situations of love, sex, business, not to be misguided by fake information, unfair incentives and outright fabrications and lies is a valuable goal. This human desire for self-determination has been called a human right and civil right, documented in national codes of rule and in declarations of international bodies, also proclaimed by philosophers and religious leaders to follow one's moral intuitions and/or God's

2 Cf. Xiaomei Zhai, "Diversified and in Harmony, but not Identical," Asian Bioethics Review 3, no. 1 (2011): 31-35. 
commandments. For millennia, religions of all sorts have played and still play important roles in human self-understanding, in our contemplation and calculation, in particular when lies become complex, and painful. ${ }^{3}$

The mythological dragon emperor Fu Xi over 3000 years ago, described the interrelatedness of all living organisms in detail, including heaven-and-earth, nature, individual humans, families, communities. ${ }^{4}$ Are the interactions and complementary polarities he describes between ying and yang, light and darkness, creative and receptive, strong and weak, firm and yielding, male and female, etc. and the 8 elements and powers of interaction (dragon/heaven, earth/receptive, thunder/arousing, water/abysmal, mountain/stillness, wind/gentleness, fire/clinging fire, lake/joyousness) just prescientific models explaining how the worlds of living beings including humans function, advising us on how to survive and live happily and healthy depending on our different personal natures and biotopes, expressing the same understanding of interrelatedness as Einstein's model of physics, or Watson's and Crick's deciphering of DNA, empowering and impacting in special combinations of all individual, biological, social, political, and corporate beings?

\section{The Bio-Ethical Imperative}

Is it selfish or altruistic to make love, to cooperate with colleagues and neighbors, to help fellow humans in need, to be kind to the microbes in our intestine? Fritz Jahr, an educator and Protestant pastor in the small German university town Halle a. d. Saale, argues that this is the wrong question and that interaction and integration, cooperation and competition are as essential for us humans as they are for all forms of life. Elsewhere I have identified the $8 \mathrm{C}$ 's essential for all forms of life, but in a special form for each species including human beings: communication and cooperation, competence and competition, contemplation and calculation, compassion and cultivation ${ }^{5}$. We find these $8 \mathrm{C}$ 's in different combinations and strengths in all species, also differently in individuals of most species. Some species are more eusocial than we humans are. Ants and bees use these $8 \mathrm{C}$ 's to fully integrate as individuals into seeking the common good of their colony ${ }^{6}$. Individual eusocial insects never betray their community,

3 Hans Martin Sass, "Significance of Religious Beliefs in End-of-Life Decision Making," Mulla Sadra, Logic and Ethics 8, (1999): 203-218 [Islam-West Philosophical Dialogue, Congress on Mulla Sadra, Tehran 1999].

4 James Legge, "The Yi King," in The Sacred Books of the East, vol. XVI, (Oxford: Clarendon, 1882); Richard Wilhelm, The I Ching Book of Changes (London: Routledge, 1968); google: The 8 Trigrams of the I-Ching [visited 09-10-18].

5 Hans Martin Sass, Cultures in Bioethics (Zuerich: Lit, 2016), 41-56.

6 See also Kai Strittmatter, Die Neuerfindung der Diktatur (Muenchen: Piper, 2018). 
but communities sometimes implode by still not well understood 'colony collapse disorder'. We humans would strongly reject the Nazi slogan 'you are nothing, your Volk is everything' and condemn the voluntary or manipulated suppression of individuality by hormones, social majorities, dictators, and slave owners.

We humans can and do hurt, betray, extort, violate, torture and kill other humans and harm human communities. Abel slayed his brother Cain with his bare hands or with a stick; weapons such as axes have been developed to destroy forests and build houses, but they also have and will continue to be used to kill fellow human beings. Our tools and technologies have a double-purpose for both good and bad. We have built living rooms, prison rooms and prayer rooms, torture chambers and court chambers, concert halls, academic halls and disco halls. Not being inflexibly eusocial such as ants and bees, we have also built orientational tools in religions, morals, laws, and philosophies across cultures, similar to our producing agricultures, cities and technologies for a better and healthier life. Socrates once argued against Euthyphron that our ethics and eusocial rules were not given by the Gods, but loved by the Gods and by good people because they are profitable, good and successful ${ }^{7}$. Cultural, religious and political human history demonstrate that social coherence, communities have been based on quite different orientational visions and religious beliefs. But those same visions have also often caused the most inhumane actions such as the burning of the inhabitants of Jericho to the gas-chambers of the Nazis, and in all other persecutions and tortures of fellow humans who were considered to be unfit to live for reasons of religion, color of skin, sex, or simply a different opinion.

We humans have other shortcomings, we cannot fly like birds and cannot swim as well as fish, but we have compensated these 'shortcomings' by developing airplanes and ships. We have transformed this earth more than any other species by building houses, farms, castles, skyscrapers and cities, our own huge networks of electricity, traffic, production and science, of communication and cooperation in both geospace and cyberspace; most recently we have extended our experiences and interactions in cyberspace from religious contents towards support of internet-based networks of people, things and everything into revolutionary new interactions and integration of geospace-cyberspace. No other species has modified and cultivated our globe more than we humans have. Are these 'shortcomings' in our 8-C capacities rather divine gifts from creation unparalleled by those of any other species, - good enough to be called 'beneficial knowledge'?

7 Platon, Euthyphron, 9b.

8 Cf the hadith by the Prophet Muhammad, Tirmidhi, "Kitab al-İlm",19: 'God, His angels and all those in Heavens and on Earth, even ants in their hills and fish in the water, call down blessings on those who instruct others in beneficial knowledge'. 
The Bioethical Imperative 'Respect every living being as an end in itself and treat it, if possible, as such ${ }^{\text {, }}$, was first formulated and presented by Fritz Jahr in 1926 as an alternative and an extension to Immanuel Kant's Categorical Imperative of 1787 'Act in such a way that you treat humanity, whether in your own person or in the person of any other, never merely as a means to an end, but always at the same time as an end' ${ }^{10}$. Both Imperatives can both be understood in their extremes either as clever egoism or as an altruistic charity; but in reality, they express a deep insight into and respect for basic interdependencies of living entities which are healthy and positive not only for myself but for all sides involved. The biblical book of Genesis bases the existence of creation in a divine act 'in the beginning GOD created the Heavens and the Earth'; an old Chinese saying holds 'Heaven and Man are an integral One; as a result, they are in constant pursuit of harmony between humanity and nature'. ${ }^{11}$ Jahr's article of 1926 was subtitled 'Old Knowledge in new Clothing'; the word 'bioethics' coined by him was just a new word for traditional wisdom in all cultures and religions. Van Rensselar Potter, an oncologist at Madison, Wisconsin, used the term 'bioethics' in most pressing and urgent wording: 'mankind is in urgent need of new wisdom that will provide the knowledge of how to use knowledge for man's survival, ... science of survival must be more than science alone, and I therefore propose the term 'bioethics' in order to emphasize ... the new wisdom that is desperately needed: biological knowledge, human values, ... it is the foundation on which we build ecology, which is the relation among plants, animals, man, and the physical environment ${ }^{12}$.

The Bioethical Imperative formulated by Fritz Jahr in 1926 was a new word, but the concept and the challenge to the health and happiness of our species, individually and collectively, and to our biotopes and the globe, has been there for millennia. The prophet Micah and Jesus have defined the bioethics requirement in most simple terms 'love your neighbor as you love yourself' ${ }^{13}$. The Vedic phrase 'tat tvam asi' - this is also you: the rat, the plant, the biotope, the city community,

9 Jahr, Fritz, "Life Sciences and the Teaching of Ethics," in Fritz Jahr: Essays in Bioethics 19241948, edited by Irene M. Miller and Hans Martin Sass (Zuerich: Lit, 1926), $20 \mathrm{f}$.

10 Kant, Immanuel, Grounding for the Metaphysics of Morals (New Haven: Yale University Press, 2002), 36 [4:429].

11 Genesis 1:1; the Chinese slogan quoted by Pan Yue (Vice Minister for Environmental Protection, PRC) in China Daily 07-27-06.

12 Van Rensselaer Potter, "Bioethics: the Science of Survival," Perspectives in Biology and Medicine 14, (1970): 127-153.

13 Matth, 22:39, also Leviticus, 19:18; cf. 1 John, 4:20: 'If anyone says, "I love God," but hates his brother, he is a liar. For anyone who does not love his brother, whom he has seen, cannot love God, whom he has not seen.' 
the suffering fellow human, the cut and dying rose in a vase - is shorter and more inclusive, but surely would be supported by Jesus, Mohammed, Buddha, Lao Zi and Confucius. The lack of firm and inflexible genetic heritage has turned out to not be a negative but a positive because it gave rise to a previously unknown richness in human social and cultural bios. Jewish rabbi and enlightened philosopher Moses Mendelsohn embraces and supports this diversity: 'Brethren, if you want true peacefulness in God, let us not lie about consensus when plurality seems to have been the plan and goal of providence. No one among us reasons and feels precisely the same way as the fellow-human does. Why do we hide from each other in masquerades in the most important issues of our lives, as God not without reason has given each of us his/her own image and face? ${ }^{\prime 4}$.

\section{The Many Faces and Colors of the Bioethics Imperative}

Jahr's reasoning centers around the Bioethics Imperative. He reviews the impact of science and technology on human ethics and it may guide the systematic study of human conduct in the areas of the life sciences and of personal, professional and public moral commitment and conduct towards all other forms of life. As an educator he examines new knowledge and related conduct and commitment in the light of traditional moral values and principles. Thus, he develops the vision of Bioethics as a discipline, a principle, and a virtue in close discussion with Kant, extending and modifying the formal Categorical Imperative towards a more encompassing and accommodating content-based Bioethical Imperative, which has to take the struggle for life as a central issue of life into account; integrated and interacting struggle for life is an essential expression in all bios.

(1) A new Academic Discipline: The Bioethical Imperative is a necessary result of moral reasoning in the Humanities, based on empirical physiology and psychology of humans, plants, and animals. As such it needs to develop, to educate and to steward personal and collective cultural and moral attitudes, it calls for new respect and responsibilities towards all forms of life. The 'Sanctity of Life' is the foundation of Jahr's 1927 Bioethical Imperative, while 1788 Kant named the 'Sanctity of the Moral Law' as the foundation of the Categorical Imperative: 'The moral law is sacred (inviolable). The person is not sacred, but humankind in his person must be recognized as sacred. Everything in the entire creation, if one wants and has power over it, can be used as a means only; only the human person

14 Moses Mendelsohn, Jerusalem oder ueber religiose Macht und Judentum (Ofen: Burian, 1819), 201. - Does the Ibn 'Umar hadith expresses a similar transreligious broad-mindedness and tolerance as we see in Socrates, Mendelsohn and other religious leaders, when we read: 'A fruitful believer remains at liberty regarding his religion, unless he kills or hurt someone unlawfully' (Bukhari). 
and with it every intelligent being is an end in himself. He is the subject of the moral law, which is sacred, based on the autonomy of his will' ${ }^{15}$. It is interesting to see, how precisely Jahr quotes new scientific publications in developing an ethical response to most recent scientific information.

(2) A new Basic Virtue Ethics: The Bioethical Imperative is based on historical and other evidence that 'compassion is an empirical established phenomenon of the human soul'. There is 'wrong love' and 'true love', however. The old lady fattens her poodle while letting her servants suffer, displays false love and compassion similar to those who practice corruption, favoritism, and unfair dealings with fellow humans ${ }^{16}$. Jahr argues that animal protection has a positive effect on ethical behavior towards humans and that even those, who do not accept his integrative bioethical reasoning, should accept animal protection as part of a culture of civilized and moral behavior among humans.

(3) A new Golden Rule: The Bioethical Imperative strengthens and complements moral recognition and duties towards fellow humans in the Kantian context and should be followed in respect of human culture and mutual moral obligations among humans. The Bioethical Imperative, based on compassion and love, cannot allow itself the Kantian luxury of just being formal. The Bioethical Imperative also is rigorous and categorical in its requirement to make deliberate pragmatic, situational, and prudent moral choices in respecting all forms of life. The golden rule is not to promote one single principle over the others, rather to balance principles depending on situations and parties involved.

(4) A new Personal Health Care rule and ethics: The Bioethical Imperative includes obligations towards one's own body and soul as a living being. For Jahr, who primarily was interested in the wider aspects of recognizing and teaching bioethical virtues and principles, moral duties towards one's own body and soul provide the bridge to biomedical ethics and public health ethics in the contemporary sense and towards interactive and interrelated goals and visions in personal and public health and hygiene, also in personal and public morality.

(5) A new Public Health Care rule: Educator and pastor Jahr voices a critical and quite conservative view towards public health issues associated with moral and cultural changes during the 20ties and 30ties of the last century. Going strong against the zeitgeist, he argues that fulfilling obligations towards oneself is also a duty towards others and towards public health, underlining the close interaction

15 Kant, Grounding for the Metaphysics of Morals, A156.

$16 \mathrm{Jahr}$, "Life Sciences and the Teaching of Ethics," 36. 
of personal care for health and public health care, also the dangers of addiction to alcohol and smoking. Jahr would not have supported the particularization of modern clinical practice into more and more specialized disciplines with less and less communication and cooperation within the clinic and with the social biotopes of the hospital. Hospitals are corporate bios, they should have a healthy internal metabolism and need to earn a reputation as good corporate neighbors within their social and cultural biotope. ${ }^{17}$

(6) A new Global Stewardship rule: Jahr broadens the $5^{\text {th }}$ Commandment 'thou shall not kill' into a universal rule and ethics of positively and proactively caring for the health and life of this globe as a part of a living cosmos: 'This all shows the universal importance of the $5^{\text {th }}$ Commandment, which needs to be employed in regard to all life. ${ }^{18}$ Rewriting the $5^{\text {th }}$ Commandment results in the Bio-ethical Imperative: Respect every living being on principle as a goal in itself and treat it, if possible, as such!'

(7) A new Corporate Ethics: The Bioethical Imperative has to recognize, to steward, and to cultivate the struggle for life among forms of life and natural and cultural living environments. Thus, social environments need similar attention as natural biotopes. Jahr uses the then popular term biozoemose ${ }^{19}$ defined by R. H. France, for living environments. Thus, his bioethical model of interacting forms of life in a living environment - similar in natural or social or economic or political environments - would include social institutions such as those for health care. Jahr has not elaborated in detail on these life forms, which consists of individuals and groups, but which have their own interest in life, in success, recognition and survival. They will develop their own personal identity, corporate or institutional ethics and attitude as a good or bad corporate neighbor within their respective neighborhood. ${ }^{20}$ Thus, the universal Bioethical Imperative can also be detailed into specialized fields of ethics of care, such as for the internal

17 Sass, Cultures in Bioethics, 209-220.

18 Jahr, "Life Sciences and the Teaching of Ethics," 77-84.

19 Eisler, ed., Wörterbuch der philosophischen Begriffe (1927), vol.1, 226.

$20 \mathrm{Jahr}$ was not an expert in economics, but he would have definitely agreed with the findings of a recent most influential article describing corporations as living beings integrated within larger living biotopes: 'Complex adaptive systems are often nested in broader systems. A population is a CAS [complex adaptive system] nested in a natural ecosystem, which in itself is nested in the broader biological environment. A company is a CAS nested in a business ecosystem, which is nested in the broad societal environment. Complexity therefore exists at multiple levels, not just within the organizational boundaries; and at each level there is tension between what is good for an individual agent and what is good for the larger system' [Martin Reeves, Simon Levin, Daichi Ueda, "The Biology of Corporate Survival," Harvard Business Review (2016): 49]- For hospitals as living and integrated corporate bodies, see also Sass, Cultures in Bioethics, 209-220. 
metabolisms of hospital wards and similar institutions of service and production. Institutions in the various fields of health care interact, serve, compete and struggle with other institutional life and have individually their own internal rules and real individuals, who in various capacities belong into these institutions. For Jahr, bioethics and environmental ethics, corporate and institutional ethics, social and sexual ethics have to follow the same principles and virtues of responsibility and respect towards natural forms of life and forms of life created by humans.

(8) A new Terminological Ethics: There is another insight we can gain from Jahr's reasoning: the need to have a clear and precise terminology. He coined the term Bioethics in order to provide for clear and distinct reasoning and resolve in our dealings with living forms of reality as different to nonliving forms, and in stewarding modern science and technology and their applications into a morally responsible way. Is it professionally and logically not correct to use such a wide term as Bioethics for more precise and distinct issues such as Medical Ethics. Therefore, we should define more precisely what we mean in clinical ethics, ethics of medical research, ethics in the care for the demented, ethics in law, ethics in politics, - just to name a few specialized fields? Spinoza in his Ethics once said 'illud omne esse verum quod valde clare et distincte percipio' (only those issues are true which we perceive clearly and distinctly) and Wittgenstein would add 'whereof one cannot speak, one must be silent'. Unclear terminology leads to unclear investigations, goals, and actions, - not only in the science but also in the humanities. If ethics and every-day attitudes can learn anything from science, then the fact, that precision in definition is a priority and a precondition for clear conceptual and practical work, for communication and for cooperation and for further development. ${ }^{21}$

(9) A new Ethics of Differentiation: Jahr, when coining the term Bioethics followed the differentiation in the terminology of the most modern sciences, psychology and physiology in particular, which had developed a term bio-psychik - not in use anymore today - for analyzing forms of living nature from other forms of non-living nature. Unclear terminology leads to unclear reasoning and acting; it is an expression of unclear thinking itself. There are different terms available for different subjects, fields, and issues: bioethics, medical ethics, hospice ethics, health policy ethics, hospital ethics, biomedical ethics, medical research ethics, physician's ethics, nursing ethics, health care ethics, nursing ethics, public health ethics, prevention ethics, gene ethics, consultation ethics, environmental ethics, animal ethics, global ethics - just to name a few. Also, ethics and cultures for handling machines and tools need to be developed along the development from

21 For the term 'bioethics' cf. Hans Martin Sass, "Bioethik/Bioethics," Archiv für Begriffsgeschichte 56 (2014): 221-228. 
axes, steam engines, autos, planes, and cellphones. These inventions have become an essential part of our daily bios, such as cellphones, cars and televisions and they are just tools. Recently, the question has been raised whether we owe complex tools such artificial algorithms digesting enormous numbers of big data and developing and implementing on their own strategies for influencing and changing networks and biotopes. Jiwon Shim has raised the question whether, different to steam engines and cars, these artificially intelligent robots should be recognized and dealt with as living entities and not as machines. ${ }^{22}$ Will we have to develop strategies to defend human individuals and biotopes against Artificial Intelligence as we have developed strategies against wild animals and destructive people?

(10) A new Ethics of Interaction: For Jahr, animal ethics and social ethics are different fields, but they interact and integrate, bringing different shapes and shades of the Bioethical Imperative together and describing the multitude of ethical obligations, some reciprocal among humans, some more or less paternal/ maternal in compassionate charities caring for the weak, frail, and disabled, some in stewarding plants and animals as co-creatures, others in mitigating or creating natural and social environments as human habitats. Those moral obligations and opportunities will and must overlap and interact in different ethical, philosophical and cultural models of personal, professional or institutional ethics, - medical ethics including prevention, treatment, care, research, - bioethics covering respect for and duties to all forms of life, environmental ethics accepting responsibility for natural and man-manipulated environment and their sustained survival and health. Nothing else is needed for the expertise and ethos of environmental ethics, land ethics, and he ethics of global responsibility in personal and in corporate and institutional ethics than a universal prudent and reasonable application of the Bioethical Imperative.

22 Jivon Shim, "Practical Methodology for Bio-ethical Imperative of Fritz Jahr," in 1926-2016 Fritz Jahr's Bioethics: A Global Discourse (Zuerich: Lit, 2017), 163-175. - When steam engines or cars malfunction, something must be broken and additional safety features did not work; when AI 'machines' do not what they are programmed for to do, then they may malfunction as well or they have ventured into new fields of decision making by destroying or modifying biotopes and networks, similar to attacking military armies in the past. AI logical and calculating powers are much higher than those of any human individual; already my small handheld calculator is much superior to my capacities. Do we need to differentiate between logical, calculating, emotional, social intelligence and refuse to include logical and calculating bios in machines, animals, plants and humans in our bio-ethical responsibilities? 


\section{Who Protects and Cultivates Bios and Biotopes?}

Natural and cultivated biotopes, human technologies, religions and cultures have changed and will continue to change, as everything has changed for billions of years, sometimes more rapidly, sometimes in more protective modes, sometimes in successful ways, sometimes with destructive results. 'Panta rei', i.e. everything changes: 'You never walk through the same river' said one of the early Greek philosophers. Also, the more complex an individual bios or biotope is, the more stable and adaptable it seems to be. ${ }^{23}$ There was - based on biological gifts of the $8 \mathrm{C}$ 's, in particular our capacities to contemplate and calculate - wisdom in all cultures of how to protect ourselves and our biotopes. Jahr's three-step interpretation of the $5^{\text {th }}$ Commandment is such an advice. Aristotle and Galen refer to the traditional Greco-Arabic four differentiations among us humans: sanguine / damawiyy, phlegmatic / balghamiyy, choleric / safrawiyy, melancholic / sauda, which are found in all of us, often mixed within one individual, also influenced by social biotopes and ready for education and therapy. Tang Dynasty physician Sun Simiao 1400 years ago differentiated between mediocre, average and superior doctors: 'a superior doctor takes care of the state, an average doctor takes care of the person, an inferior doctor takes care of the disease'. This comes close to Galen, personal doctor of Roman Emperors 2000 years ago, who defined the 'res non-naturales' as cultivated attitudes for well-balanced harmonious and happy lifestyles in 'light and air, eating and drinking, work and rest, sleep and wake, secretion and excretion, and the stimulation of the mind'. ${ }^{24}$ The four principles of the Southern Kung Fu Dragon School call for '(1) train and condition the body, (2) be righteous and uphold your honor, (3) respect your parent and honor your teacher, (4) treat others with honesty and your friends with loyalty ${ }^{25}$, go into the same direction.

Similar to us individuals, corporate, political and social bodies are different in temperament, health, strength, success and happiness. But unfortunately, the diagnosis of health and sustainability of political bodies focusses primarily on economic parameters such as GNP (Gross National Product) only. A much better diagnostic and therapeutic tools have been suggested and applied in his country since 1972 by Jigme Singye Wangchuck, the King of Bhutan: the GHP (Gross Happiness Product); it measures 'personal pride, social and cultural coherence, satisfaction, knowledge, spirituality, individual emotional and physical health, harmony with

23 Reeves, Levin and Ueda, "The Biology of Corporate Survival," 49.

24 Quoted in Sass, Cultures in Bioethics, 177f; see also Klaus Bergdolt, Leib und Seele: Eine Kulturgeschichte des gesunden Lebens (Muenchen: Beck, 1999).

$25 \mathrm{Cf}$ the internet, also Wilhelm, The I Ching or Book of Changes. 
the environment and balanced use of personal time' ${ }^{26}$ In cultures of integrated bioethics, compassion is not limited to charity to fellow-humans; all creation is included as we understand the old Vedic 'tat tvam asi'; Christian mystic Francis of Assisi called the sun and moon 'sister and brother'. The Prophet Muhammad said: 'Once a dog was going around the well and was about to die out of thirst. A prostitute of Banu Israel happened to see it. So, she took off her leather sock and lowered it into the well. She drew out some water and gave the dog to drink. She was forgiven on account of her action'27. Jahr quotes more than once German philosopher Eduard von Hartmann's critique of cutting luxury flowers: 'whenever I see a rose in a glass of water tied into a bouquet, I cannot fight the unpleasant thought that a human being has murdered a flower life for the sole purpose to enjoy his/her eyes, heartless enough to not sense the unnatural death under the appearance of life ${ }^{28}$. Can we generalize these wide and inclusive understandings of charity and compassion by respecting all bios within an integrated biotope and creation? Can hospitals in recognition of their integrated service in expertise and ethics, and in competence and compassion, serve as role models for other corporations, for villages and cities, for religious communities and scientific circles?

2500 years ago, Lao Zi suggested a recipe for healthy and happy living of individual and integrated bios: 'cultivate yourself and virtue will become true; cultivate the family and virtue will be complete; cultivate the village and virtue will grow; cultivate the country and virtue will be rich; cultivate the world and virtue will be wide'. ${ }^{29}$ May we redefine Lao Zi's recommendation for the

26 Policy Innovations, in: http://www.policyinnovations.org/ideas/briefings/data/000098/; Bhutan GNH, $11^{\text {th }}$ Five-Year-Plan 2012-2018 'Self-Reliance and Inclusive Green Socioeconomic Development. GNH Foundation, XIX and $467 \mathrm{pp}$; in $20158.4 \%$ of the population were deeply happy, $35 \%$ extensively happy, $47 \%$ narrowly happy, $8.8 \%$ unhappy; this was a $1.8 \%$ improvement over the figures of 2010; cf Joseph Devine, Timothy Hinks, and Arif Naveed, "Happiness in Bangladesh: The Role of Religion and Connectedness," Journal of Happiness Studies (2017): 1-21

[https://link.springer.com/article/10.1007/s10902-017-9939-x/fulltext.html.- It has been estimated that in economic terms business loses 350 billion US\$ every year due to unhappy workers; cf various wikipedia articles for more detailed information. - The actual 2013-2018 plan details goals and estimates of cost for the support of infrastructure, communication, internet, schools, local communities, trade, environment, renewable resources, vulnerable populations, and the elderly. The index now includes eight pillars with greater specificity as general contributors to happiness: 'physical, mental and spiritual health; time-balance; social and community vitality; cultural vitality; education; living standards; good governance; ecological vitality'. The United Nations in 2012 adopted this concept of happiness and defined happiness as a human right and a 'fundamental human goal'.

27 Bukhari, "Kitab al-Anbiya", 54; Muslim, "Kitab al-Salaam”, 155.

28 Jahr, "Life Sciences and the Teaching of Ethics," 19.

29 Lao-Tzu, Dao te Ching, 54. 
21. century by saying: 'cultivate yourself and your life and virtue will be true; cultivate individual and corporate persons and virtue will be great; cultivate social and natural environments and virtue will be full; cultivate communication cooperation and life will grow; cultivate compassion and competence and life will be rich; cultivate the worlds of bios and biotopes and virtue will be wide'. Buddha, Confucius, Lao Zi, Jesus and Muhammed, also Jahr and Francesco Assisi, very likely would support such a cross-cultural Bioethical and Biopolitical Recipe for the 21the century as a challenge to all of us. The oncologist Potter in Madison, Wisconsin, would have added: 'This is urgent!'

\section{References}

Bergdolt, Klaus. Leib und Seele: Eine Kulturgeschichte des gesunden Lebens. Muenchen: Beck, 1999.

Devine, Joseph, Timothy Hinks, and Arif Naveed. "Happiness in Bangladesh: The Role of Religion and Connectedness." Journal of Happiness Studies (2017): 1-21.

Eisler, ed. Wörterbuch der philosophischen Begriffe. 1927.

Jahr, Fritz. "Life Sciences and the Teaching of Ethics." in Fritz Jahr: Essays in Bioethics 19241948. edited by Irene M. Miller and Hans Martin Sass, Zuerich: Lit, 1926.

Immanuel, Kant. Grounding for the Metaphysics of Morals. New Haven: Yale University Press, 2002.

Legge, James. "The Yi King." in The Sacred Books of the East, vol. XVI, Oxford: Clarendon, 1882.

Mendelsohn, Moses. Jerusalem oder ueber religiose Macht und Judentum. Ofen: Burian, 1819.

Potter, Van Rensselaer. "Bioethics: the Science of Survival." Perspectives in Biology and Medicine 14 (1970): 127-153.

Reeves, Martin, Simon Levin, and Daichi Ueda. "The Biology of Corporate Survival." Harvard Business Review (2016): 46-55.

Sass, Hans Martin. "Significance of Religious Beliefs in End-of-Life Decision Making." Mulla Sadra, Logic and Ethics 8 (1999): 203-218.

Sass, Hans Martin. "Bioethik/Bioethics.” Archiv für Begriffsgeschichte 56 (2014): 221-228.

Sass, Hans Martin. Cultures in Bioethics. Zuerich: Lit, 2016.

Shim, Jivon. "Practical Methodology for Bio-ethical Imperative of Fritz Jahr." in 1926-2016 Fritz Jahr's Bioethics: A Global Discourse. Zuerich: Lit, 2017.

Strittmatter, Kai. Die Neuerfindung der Diktatur. Muenchen: Piper, 2018.

Wilhelm, Richard. The I Ching Book of Changes. London: Routledge, 1968.

Zhai, Xiaomei. "Diversified and in Harmony, but not Identical." Asian Bioethics Review 3, no. 1 (2011): 31-35. 